\title{
Drug Susceptibility Pattern of Aerobic Bacterial isolates from Pulmonary Infection in HIV Seropositives and their Correlation with CD4 Count
}

\author{
Shilpa. A*, Anuradha.K, Venkatesha. D \\ Department of Microbiology, Mysore Medical College and Research Institute, Mysore - 570001Karnataka, \\ India.
}

\begin{abstract}
Background-Opportunistic pulmonary disease remains an important cause of acute illness and death in patients with advanced HIV disease. A structured approach to respiratory complaints in these can result in a timely and cost-effective evaluation Materials and methods-Sputum and blood samples were collected from 100 HIV seropositives with lower respiratory tract infection. Sputum processed for bacterial pathogens. Antimicrobial susceptibility testing was done using Kirby-Bauer disc diffusion method. CD4 count was estimated using blood sample by Flow cytometry method.Results-Among100 samples92yielded growth. The isolates were $62.09 \%$ bacteria, $37.9 \%$ fungal and $35 \%$ polymicrobial. Aerobic bacterial isolates were Klebsiella spp.,22(17.74\%), Streptococcus pneumoniae21(16.94\%),others Acinetobacter spp., Staphylococcus aureus., Pseudomonas aeruginosa, Enterobacter spp., and E.coli. Acid Fast Bacilli and Nocardia were demonstrated in $22 \% \& 1 \%$ respectively. Staphylococcus aureus was resistant to most antibiotics but all strains were sensitive to vancomycin. Streptococcus pneumoniae was sensitive to all. Gram negative isolates showed resistance to ampicillin, $\beta$-lactams and co-trimoxazole. They were sensitive to ciprofloxacin, gentamicin and imipenem .CD4 count in most of them were < 200. Conclusion-It is important to identify aetiological agent with antibiotic sensitivity for a better choice of antibiotic regimens in view of emerging bacterial resistance in pathogens infecting HIV seropositive patients.
\end{abstract}

Key words: bacterial infection, CD4 count, drug resistance, HIV seropositives

\section{Introduction}

The HIV/AIDS pandemic has severely affected health development and eroded improvements in life expectancy, particularly in countries with the highest prevalence of infection. [1]It cannot be understated that infection with human immunodeficiency virus type 1 (HIV-1; HIV infection) has become the defining viral infection of the past three decades, if not of the past century. [2]South \& South East Asia in 2010 contained an estimated 4 million cases or $12 \%$ of all people living with HIV resulting in approximately 250,000 deaths. Approximately 2.4 million of these cases are in India.[3]

Opportunistic infections (OI) have been recognized as common complications of HIV infection responsible for substantial morbidity, hospitalization and mortality. The decrease in CD4+ count leads to various OIs in HIV-infected persons. The relative frequencies of specific opportunistic diseases may vary in different countries and different areas within the same country. Little information is available about the prevalence of OIs in different parts of India, considering the vastness of the country. [4]

Respiratory tract infections are a major cause of significant morbidity and mortality in HIV patients. [5] The clinical spectrum of pulmonary disease is broad and geographic and temporal variations in the etiology of respiratory illnesses in HIV-infected patients are important. There is very wide range of pathogens responsible for respiratory diseases [6]

In sub Saharan Africa and Asia the most common pulmonary complication in HIV infected individuals is tuberculosis.[7] Pyogenic bacterial infections are common in patients with AIDS and are an important cause of death in Africa. [8]Bacterial pneumonia has emerged as an important cause of pulmonary morbidity in recent years, as a growing number of patients have risk factors for bacterial infections, including injecting drug use and smoking cigarettes and other drugs. [9] Bacterial pneumonia rates were up to 25-fold higher among HIVinfected adults than in the general community, with rates increasing as CD4+ T-cell count decreases. [10]

Hence, this study was undertaken to know the aerobic bacterial etiological agents causing lower respiratory tract infection and their susceptibility pattern in HIV sero-positive patients and their correlation with the level of CD4+ T lymphocytes.

\section{Materials and Methods}

The present study was conducted in the department of Microbiology, Mysore Medical College and Research Institute, Mysore on patients who are HIV seropositive and visit the ART centre, K.R. Hospital, 
Mysore. An informed consent was taken from study group and the necessary clinical details were noted in the proforma prepared for the purpose.

2.1 Study group-A total number of 100 patients diagnosed as HIV reactive as per the NACO guidelines [11] with clinical symptoms and signs of lower respiratory tract infections were included for the study. Expectorated sputum samples and $5 \mathrm{~mL}$ of blood were collected for isolation of pathogen and estimation of CD4+ count respectively.

2.2 Sputum processing- Smears were prepared from the thick purulent part and subjected to Gram's staining to know the cellularity and presence of organisms. Ziehl-Neelsen staining to demonstrate Acid fast bacilli as per RNTCP guidelines.[12] The specimens were inoculated onto Chocolate agar, MacConkey's agar and incubated at $37^{\circ} \mathrm{C}$ for $18-24 \mathrm{hr}$, in humid air and $5-10 \% \mathrm{CO}_{2} \cdot[13]$ The significant bacterial growth was further processed as per the standard procedure to identify the pathogens.[14]

Kirby-Bauer disc diffusion method was performed for antibiotic susceptibility testing on Mueller Hinton agar as per CLSI guide lines using commercially procured discs(HiMedia)

2.3 Blood specimen was subjected for determination of CD4+ lymphocyte count by automated flow cytometer analyzer BD FACS caliber.

\subsection{Statistical analysis}

Descriptive statistics was applied to calculate different variables in the table and arrange them in order. The crosstabs procedures applied for two-way and multi-way tables to know the association between various tests and measures. Chi-square test procedures used for tabulation. Results were statistically analyzed by using SPSS for Windows(version16.0).

\section{Results}

Sociodemographic -In the present study majority of the patients were in the reproductive age group of $31-40$ years with mean age of 36.92 \pm 9.9 , with male:female ratio of 1.8:1. Study group comprised of $32 \%$ housewives followed by $21 \%$ labourers. $57 \%$ of the patients belonged to low socio economic strata. History of smoking and alcoholism was found in $37 \%$ and $18 \%$ respectively. Symptoms of fever, cough, chest pain and haemoptysis was noted in $78 \%, 100 \%, 3 \%$ and $2 \%$ respectively TABLE 1

TABLE 1: Sociodemographic characteristics of baseline population.

\begin{tabular}{|c|c|c|c|}
\hline & & Number(Percent \%) & $P$ value \\
\hline $\begin{array}{l}\text { Age Group } \\
0-10\end{array}$ & $\begin{array}{l}\text { Gender } \\
\text { Male } \\
\text { Female }\end{array}$ & $\begin{array}{l}1(1.6) \\
1(2.8)\end{array}$ & \multirow[t]{7}{*}{$0.736(\mathrm{NS})$} \\
\hline $11-20$ & $\begin{array}{l}\text { Male } \\
\text { Female }\end{array}$ & $\begin{array}{l}1(1.6) \\
1(2.8)\end{array}$ & \\
\hline $21-30$ & $\begin{array}{l}\text { Male } \\
\text { Female }\end{array}$ & $\begin{array}{l}11(17.2) \\
12(33.3)\end{array}$ & \\
\hline $31-40$ & $\begin{array}{l}\text { Male } \\
\text { Female }\end{array}$ & $\begin{array}{l}29(45.3) \\
11(30.6)\end{array}$ & \\
\hline $41-50$ & $\begin{array}{l}\text { Male } \\
\text { Female }\end{array}$ & $\begin{array}{l}17(26.6) \\
6(16.67)\end{array}$ & \\
\hline $51-60$ & $\begin{array}{l}\text { Male } \\
\text { Female }\end{array}$ & $\begin{array}{l}4(6.3) \\
5(13.9)\end{array}$ & \\
\hline $61-70$ & $\begin{array}{l}\text { Male } \\
\text { Female }\end{array}$ & $\begin{array}{l}1(1.6) \\
-\end{array}$ & \\
\hline Occupation Agriculture & $\begin{array}{l}\text { Middle income* } \\
\text { Low income* }\end{array}$ & $\begin{array}{l}5(5) \\
7(7)\end{array}$ & \multirow[t]{6}{*}{$.000(\mathrm{~S})$} \\
\hline Driver & $\begin{array}{l}\text { Middle income* } \\
\text { Low income* }\end{array}$ & $\begin{array}{l}8(8) \\
1(1)\end{array}$ & \\
\hline Business & $\begin{array}{l}\text { Middle income* } \\
\text { Low income* }\end{array}$ & $\begin{array}{l}13(13) \\
5(5)\end{array}$ & \\
\hline Laborer & $\begin{array}{l}\text { Middle income* } \\
\text { Low income* }\end{array}$ & - $21(21)$ & \\
\hline Housewife & $\begin{array}{l}\text { Middle income* } \\
\text { Low income* }\end{array}$ & $\begin{array}{l}17(17) \\
15(15) \\
\end{array}$ & \\
\hline Miscellaneous & $\begin{array}{l}\text { Middle income* } \\
\text { Low income* }\end{array}$ & $\begin{array}{l}- \\
8(8)\end{array}$ & \\
\hline Habits & $\begin{array}{l}\text { Smokers } \\
\text { Alcoholics }\end{array}$ & $\begin{array}{l}37(37) \\
18(18)\end{array}$ & \\
\hline Symptoms & $\begin{array}{l}\text { Cough with expectoration } \\
\text { Fever } \\
\text { Chest pain } \\
\text { Haemoptysis }\end{array}$ & $\begin{array}{l}78(78) \\
100(100) \\
3(3) \\
2(2)\end{array}$ & $.000(\mathrm{~S})$ \\
\hline Prophylaxis & $\begin{array}{l}\text { On CPT** } \\
\text { On ART** }\end{array}$ & $\begin{array}{l}2(2) \\
29(29)\end{array}$ & \\
\hline
\end{tabular}


*modified B G Prasad classification (2010) - middle: 2105 - 7014 Rs. per month; low: < 2104 Rs. per month. ** CPT: co-trimoxazole prophylaxis, ***ART: anti-retroviral treatment.

In the study group92out of 100 sputum samples yielded growth of 147 pathogens which included62.09\% aerobic bacteria, acid fast bacilli in $22 \%$ and $1 \%$ nocardia, $37.9 \%$ fungal and polymicrobial infection either mixed bacterial or bacteria with fungus was seen in $35 \%$. Aerobic bacterial organisms isolated in the study are shown in TABLE 2.

Table 2: Various pathogens isolated from the samples

\begin{tabular}{|l|l|}
\hline Organisms & Number(\%) \\
\hline Klebsiella & $22(14.96 \%)$ \\
\hline Acinetobacter spp. & $8(5.44 \%)$ \\
\hline Pseudomonas aeruginosa & $7(4.76 \%)$ \\
\hline E.coli & $5(3.4 \%)$ \\
\hline Enterobacter & $5(3.4 \%)$ \\
\hline Serratiamarcescens & $1(0.68 \%)$ \\
\hline Streptococcus pneumoniae & $21(14.28 \%)$ \\
\hline Staphylococcus aureus & $7(4.76 \%)$ \\
\hline Enterococcus spp & $1(0.68 \%)$ \\
\hline
\end{tabular}

Significant association was found between low CD4 cells counts of $\leq 200$ cells/ $\mathrm{ml}$ and the occurrence of opportunistic infections with bacterial and Mycobacterium tuberculosis. TABLE 3

Table 3: Distribution of pathogens based on CD4+ count

\begin{tabular}{|c|c|c|c|c|c|c|c|c|c|c|c|c|c|c|}
\hline \multirow{2}{*}{$\begin{array}{l}\text { CD4 count } \\
\text { (cells/ml) }\end{array}$} & \multirow[t]{2}{*}{ No. (\%) } & \multirow[b]{2}{*}{ 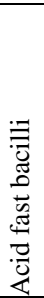 } & \multirow[b]{2}{*}{ 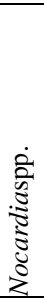 } & \multicolumn{7}{|c|}{ Gram negative bacilli } & \multicolumn{4}{|c|}{ Gram positive cocci } \\
\hline & & & & $\underset{0}{\tilde{0}}$ & 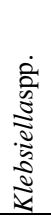 & 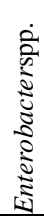 & 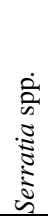 & $\begin{array}{l}\dot{2} \\
2 \\
0 \\
0 \\
0 \\
0 \\
0 \\
0 \\
0 \\
0 \\
0\end{array}$ & 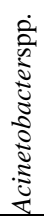 & $\frac{\pi}{3}$ & 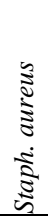 & 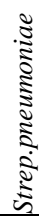 & 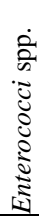 & $\frac{5}{5}$ \\
\hline$<50$ & $15(15)$ & 2 & 1 & 1 & 2 & & & 3 & 2 & 8 & 1 & 3 & & 4 \\
\hline $50-100$ & $14(14)$ & 1 & & & 8 & 1 & & 1 & 2 & 12 & & 1 & & 1 \\
\hline $101-200$ & $23(23)$ & 5 & & 2 & 2 & 3 & 1 & & 2 & 10 & 4 & 4 & & 8 \\
\hline $201-300$ & $20(20)$ & 7 & & 1 & 5 & & & & 1 & 7 & 1 & 6 & & 7 \\
\hline $301-400$ & $8(8)$ & 4 & & & 2 & 1 & & & 1 & 4 & & & & 0 \\
\hline $401-500$ & $11(11)$ & 2 & & & 2 & & & 1 & & 3 & & 4 & 1 & 5 \\
\hline$>500$ & $9(9)$ & 2 & & 1 & 1 & & & 2 & & 4 & 1 & 3 & & 4 \\
\hline Total & 100 & 23 & & 5 & 22 & 5 & 1 & 7 & 8 & 48 & 7 & 21 & 1 & 29 \\
\hline
\end{tabular}

Antibiotic susceptibility pattern of Gram negative isolates, showed resistance to ampicillin, $\beta$-lactams and cotrimoxazole. Most of the isolates were sensitive to ciprofloxacin, gentamicin and imipenem TABLE 4.

Table 4: Antibiotic resistance pattern of Gram negative bacilli

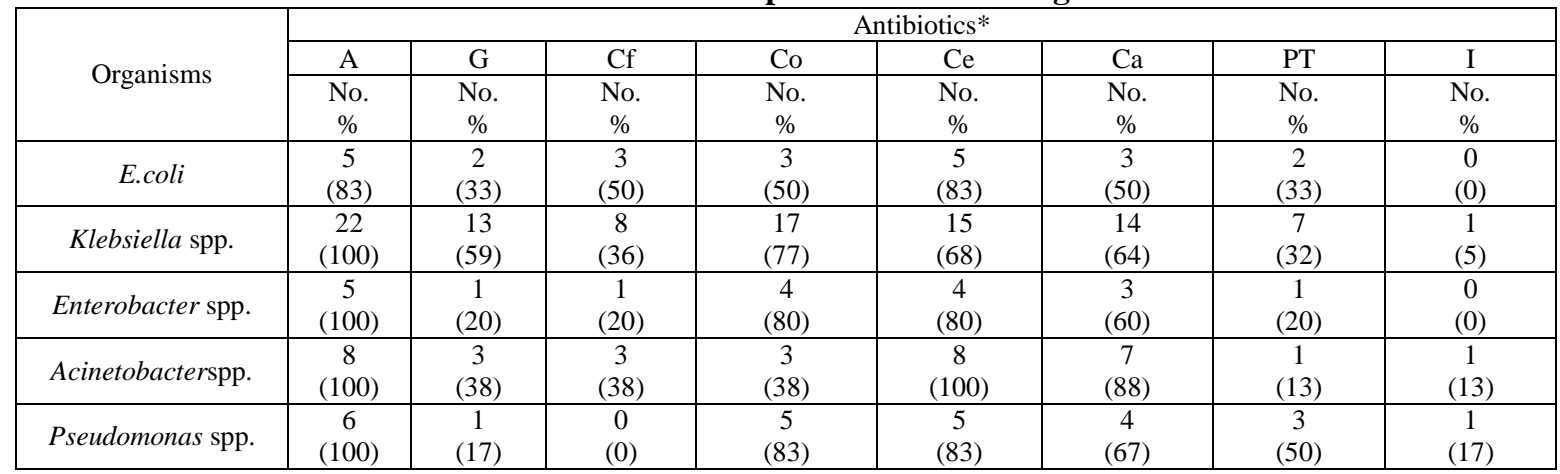

*A-ampicillin; G-gentamycin; Cf-ciprofloxacin; Co-cotrimoxazole; Ce-cefotaxime; Ca-ceftazidime; PTpiperacillin-tazobactam; I-imipenem.

Staphylococcus aureus was resistant to penicillin (86\%), erythromycin (71\%), cotrimoxazole (57\%) and ciprofloxacin $(43 \%)$, all strains were sensitive to gentamicin and vancomycin. Streptococcus pneumoniae was sensitive to all antibiotics. 


\section{Discussion}

NACO report says that more men are HIV positive than women. Nationally, the prevalence rate for adult females is $0.29 \%$, while for males it is $0.43 \%$. Prevalence is also high in 15 to 49 age group $88.7 \%$ of all infections), indicating that AIDS still threatens the cream of society, those in the prime of their working life. In our study also $86 \%$ of them are 21-50years.

People with advanced human immunodeficiency virus are vulnerable to infections called "opportunistic infections" because they take the advantage of the opportunity offered by a weakened immune system.[15]Opportunistic infections in AIDS generally results from reactivation rather than from primary infection. [16]

The high frequency of detection of HIV proviral DNA in alveolar lymphocytes and alveolar macrophages from patients with AIDS indicates that the lung is a major focus of disease in patients with acquired immunodeficiency syndrome. [17]The most common manifestation of pulmonary disease is pneumonia. The two most common causes of pneumonia are bacterial infections and Pneumocystis jiroveci infection. [18]Although HIV affects cell-mediated immunity most profoundly, abnormality in antibody production and neutrophil dysfunction in advanced AIDS contribute to the increased risk of bacterial pneumonia.[19]

In our study $62.09 \%$ aerobic bacteria isolated and $22 \%$ mycobacteria was demonstrated this correlates with study by Usman $\mathrm{AD}$ et al. [20]

Streptococcus pneumoniae are intrinsically virulent encapsulated bacteria, these infections may occur at any stage of HIV disease. In HIV-related bacterial pneumonia Streptococcus pneumoniae is the common pathogen followed by Haemophilus influenzae.[21]In the present study, Streptococcus pneumoniae14.28\%[22] Staphylococcus aureus was isolated in 4.76\%[23] Methicillin-resistant Staphylococcus aureus pneumonia can be quite severe and commonly leads to cavitation.[19]

Enterobacteriaceae is the main pathogens isolated with the predominating organism Klebsiella spp.( 14.96\%) which correlates with other studies [24][25].The other pathogens like E.coli3.4\% [22] Enterobacter spp.,3.4\% and Serratia marcescens $0.68 \%$ isolated correlated with various studies.[24][22] Acinetobacter spp.5.4\%gram negative non fermenter was isolated, similar results observed in other studies also.[22][23][24]

Opportunistic infections with nocardia are rare compared with other may be due to the frequent use of trimethoprim-sulfamethoxazole for PCP prophylaxis. The disease is usually sub-acute to chronic, and limited to the lung, where cavitation may occur. [19]Similarity was observed with other studies in isolation of Nocardia spp., [25][22]

The antibiotic susceptibility pattern of Gram negative organisms in the present study shows increased resistance to ampicillin, $\beta$-lactams and cotrimoxazole, which correlates with others.[26][24]Most of the isolates were sensitive to gentamicin, ciprofloxacin and imipenem and this correlated with study.[27]Staphylococcus aureus was found resistant to penicillin (86\%), macrolides (71\%), cotrimoxazole (57\%) and ciprofloxacin (43\%). Out of 7 isolates, 4 were methicillin resistant and all strains were sensitive to vancomycin. This correlates with Madhi SA et al.[26]

CD4 T lymphocytes are the primary targets of HIV. The relentless destruction of CD4 T lymphocytes by HIV, results in the loss of HIV-specific immune response, recall antibody response and, finally, non-specific immune response in the AIDS stage.[28]The progressive loss of CD4 T lymphocytes eventually results in the loss of an ability to mount desirable immune response to any pathogen and vulnerability to opportunistic pathogens characteristic of AIDS.

In the present study a significant association was found between low CD4 counts of less than $200 \mathrm{cells} / \mathrm{ml}$ and the occurrence of opportunistic infections with bacterial agents and mycobacterium tuberculosis. A similar observation was found in other studies.[20][25]

\section{Conclusions}

HIV seropositives are susceptible to lower respiratory tract infection especially pneumonia caused by various organisms. During routine CD4 count evaluation whenever there is a decrease, it should alert the clinicians to anticipate opportunistic infections. Capsulated pathogens and mycobacteria can cause infection at any stage. Routine screening of opportunistic pulmonary infection is essential to know the etiological agent and their susceptibility pattern before treating the patients empirically, as we have observed in the present study these isolates show drug resistance. So culture and sensitivity will help to adopt correct treatment which will help to reduce morbidity and mortality. 


\section{References}

[1] http://www.searo.who.int/LinkFiles/BCT_HLM-392.pdf

[2] Keith R. Jerome. Lennette's Laboratory Diagnosis of Viral Infections. $4^{\text {th }}$ Ed. New York: Informa Healthcare 2010:383-96.

[3] http://www.unaids.org/en/media/unaids/contentassets/documents/unaidspublication/2011/20111130_UA_Report_en.pdf

[4] Chakraborthy N, Mukherjee A, Santra S, Sarkar RN, Banerjee D, Guha SK et al. current trends of opportunistic infections among HIV-seropositive patients from Eastern India. Jpn.J.Infect.Dis., 61, 49-53, 2008.

[5] Feldman C, Klugman KP, Victor L. Yu, AkeOrtqvist et al. Bacteraemic pneumococcal pneumonia: Impact of HIV on clinical presentation and outcome. J Infect 2007; 55:125-135.

[6] Wallace J, Hansen N, Lavange L, et al. Respiratory disease trends in the pulmonary complications of HIV infection study cohort. Am J RespirCrit Care Med 1997;155:72-80

[7] Daley CL. Pulmonary infections in the tropics: impact of HIV infection. Thorax 1994; 49:370-8

[8] Wallace J, Rao A, Glassroth J, Hansen N, Rosen M, Arakaki C, et al. Respiratory illness in persons with HIV infection. Am Rev Respir Dis 1993; 148: 1523-9.

[9] Gerald L Mandell, John E Bennett, Raphael Dolin Mandell, Douglas and Benett's Principles and Practice of Infectious diseases. $6^{\text {th }}$ ed.Philadelphia: Elsevier Churchill Livingstone 2005; 1: 1567-73.

[10] Feikin DR, Feldman C, Schuchat A, Janoff EN. Global strategies to prevent bacterial pneumonia in adults with HIV disease.Lancet Infect Dis. 2004 Jul; 4(7):445-55.

[11] NACO: Guidelines for prevention and management of opportunistic infections/malignancies among HIV-infected adults and adolescents. Available from: http://www.nacoonline.org/upload. [Accessed on $2010 \mathrm{Jul} 10$ ].

[12] http://www.tbcindia.nic.in/pdfs/1b\%20\%20Diagnosis\%20of\%20smear\%20positive\%20pulmonary\%20TB.pdf

[13] Collee JG, Fraser AG, Marmion BP, Simmons A. Mackie and McCartney Practical Medical Microbiology. 14 ${ }^{\text {th }}$ ed. New York: Elsevier Churchill Livingstone 1996; 65.

[14] Forbes, Sahm, Weissfeld, Bailey and Scott's. Diagnostic Microbiology. $12^{\text {th }}$ ed. China : Mosby $2007 ; 629-713$.

[15] Maldarelli F. Diagnosis of HIV infection. $6^{\text {th }}$ ed. Chapter 115 Bennett's Principles and Practice of infectious diseases, Mandell, Doughlas, eds, Pennsylvania: Elsevier Churchill Living Stone; 2005, I: pp. 1506-26.

[16] Zhu T.F., B.T. Korber, A.J. Nahmias, E.Hooper, P.M. Sharp, D.D. Ho. An African HIV-1 sequence from 1959 and implications for the origin of the epidemic. Nature.1998;391:594-597.

[17] J R Clarke, D Israel-Biet. Interactions between opportunistic micro-organisms and HIVin the lung. Thorax 1996;51:875-877.

[18] Fauci SA, Lane CH. Human Immunodeficiency Virus Disease: AIDS and related disorders. In: Kasper LD, Braunwald E, Fauci SA, Hauser SL, Longo DL, Jameson LJ, editors. Harrison's Principles of Internal Medicine. $17^{\text {th }}$ ed. New York: McGraw-Hill Medical Publishing Division; 2008. p. 1076-139.

[19] John J.W. Fangman, Paul E.Sax. Human immunodeficiency virus and pulmonary functions. $4^{\text {th }}$ ed. Chapter 128 . Fishman's pulmonary diseases and disorders; 2008, vol 2:pp. 2241-2264.

[20] Usman AD. Uba A. A survey of bacterial and fungal oppurtunistic infections among HIV clients in Kano metropolis. Bayero Journal of Pure and Applied Sciences. 2011; 4(1): 148 - 152.

[21] Gerald L Mandell, John E Bennett, Raphael Dolin Mandell, Douglas and Benett's Principles and Practice of Infectious diseases. $6^{\text {th }}$ ed.Philadelphia: Elsevier Churchill Livingstone 2005; 1: 1567-73.

[22] Hirschtick RE, Glassroth J, Jordan MC, Wilcosky TC, Wallace JM. Bacterial pneumonia in persons infected with human immunodeficiency virus. Pulmonary complications of HIV Infection Study Group. N Engl J Med 1995; 333(13): 845-51.

[23] K Shreevidya, Meena Dias. Pulmonary bacterial and fungal infections in Human Immunodeficiency Virus patients: A study from India. Ann Trop Med Public Health.2012; 5:80-4.

[24] TG Castellanos, Mota IM, Rodríguez DS, Monrás MP, Ávila JP. Identification and antimicrobial sensitivity of gram negative bacteria causing pneumonia in HIV/AIDS patients. J Infect Dis.1995;171:930-7.

[25] VV Shailaja, LA Pai, DR Mathur, V Lakshmi. Prevalence of bacterial and fungal agents causing lower repiratory tract infections in patients with human immunodeficiency virus infection. Ind J Med Microbiol 2004; 22(1): 28-33.

[26] Madhi SA, Petersen K, Madhi A, Khoosal M, Klugman KP. Increased disease burden and antibiotic resistance bacteria causing severe community-acquired lower respiratory tract infections in Human Immunodeficiency Virus type-1 infected children. CID 2000; 31:170-6.

[27] Bharathi B, Siva Sankar S, SwamidossDanial. Incidence of bacterial and fungal coinfections in some HIV infected Indian population. Indian J. Biotechnol. $2010 \mathrm{Feb}$; 3(2): 199.

[28] Dybul M, Comors M, Fauci AS. The Immunology of HIV infection. $6^{\text {th }}$ ed. Chapter 116. Bennett's Principles and Practice of infectious diseases, Mandell, Doughlas, eds, Pennsylvania: Elsevier Churchill Living Stone; 2005, I: pp. 1527-45. 